\title{
Characterization of Diazotrophs Isolated from Sugarcane Rhizosphere in Different Regions of Bangladesh
}

\author{
G. M. A. Hossain ${ }^{*}$, A. R. M. Solaiman', A. J. M. S. Karim², \\ G. K. M. M. Rahman', M. A. Baset ${ }^{3}$, M. M. Rahman ${ }^{4}$ and S. Dev ${ }^{4}$ \\ ${ }^{1}$ Bangladesh Sugarcrop Research Institute, Ishurdi-6620, Pabna, Bangladesh \\ ${ }^{2}$ Department of Soil Science, ${ }^{3}$ Department of Crop Botany, ${ }^{4}$ Department of \\ Biotechnology, Bangabandhu Sheikh Mujibur Rahman Agricultural University, Salna, \\ Gazipur-1706, Bangladesh \\ *Corresponding author
}

\section{A B S T R A C T}

\section{Keywords}

Characterization, Diazotrophs, Sugarcane, Rhizosphere, Bangladesh

Article Info

Accepted:

20 February 2020

Available Online:

10 March 2020
The experiment was conducted at the Soil Microbiology Laboratory of the Department of Soil Science, Bangabandhu Sheikh Mujibur Rahman Agricultural University (BSMRAU), Gazipur during the period from January, 2011 to June, 2011 with a view to isolate and characterized promising diazotrophs from sugarcane rhizosphere. Twenty four bacterial strains were isolated from sugarcane rhizosphere soils. Among the 24 isolated strains thirteen of them were found as Gram negative and eleven were Gram positive. Seventeen of the strains were positive for cellulose activity. Fifteen of the strains were found as positive for phosphate solubilisation activity. All of these bacterial strains were evaluated for nitrogen fixation activity, among them 21 isolates were found as ARA positive. The highest ARA was found in strain Acinetobacter calcoaciticus (BUSo 9) $\left(3.74 \times 10^{-4} \mu \mathrm{mol}\right.$ $\mathrm{C}_{2} \mathrm{H}_{4} \mathrm{cfu}^{-1} \mathrm{hr}^{-1}$ ) which was statistically similar to Bacillus cereus (BUSo 13) $\left(1.54 \times 10^{-4}\right.$ $\left.\mu \mathrm{mol} \mathrm{C}_{2} \mathrm{H}_{4} \mathrm{cfu}^{-1} \mathrm{hr}^{-1}\right)$. All of the strains were found as IAA producing. Two promising strains were selected for $16 \mathrm{SrDNA}$ sequencing. From $16 \mathrm{~S}$ rDNA sequence analysis of the strains it was observed that ninety nine per cent sequence identity was observed between the 16S rDNA sequence of BUSo 9 and Acinetobacter calcoaciticus and also ninety nine per cent sequence identity was observed between the 16S rDNA sequence of BUSo 13 and Bacillus cereus.

\section{Introduction}

Biological nitrogen fixation (BNF) by diazotrophic bacteria is an important process when $\mathrm{N}$ is a limiting factor for the growth of organisms. Diazotrophic bacteria are found in symbiosis with plants forming root nodule structures, or as free-living bacteria in the rhizosphere or as associative bacteria in a large variety of plant species, mainly monocotyledons such as rice (Oryza sativa L.) (Döbereiner and Pedrosa, 1987; Khammas et al., 1989; Gillis et al., 1995; Xie and Yokota, 2005), sugarcane (Saccharum 
officinarum L.) (Döbereiner and Ruschel, 1958; Reis et al., 1994; Baldani et al., 1997), corn (Zea mays L.) (Döbereiner and Ruschel, 1958; Magalhães et al., 1979; Reis et al., 2004), and wheat (Triticum aestivum, L.) (Neal and Larson, 1976). Non-symbiotic (associative or free living) diazotrophic bacteria also promote plant growth by BNF and through the production of metabolites that stimulate root growth. High rates of nitrogen (N) fertilizer are often applied to maximize sugarcane yields. High cost for $\mathrm{N}$ fertilizers and off-site $\mathrm{N}$ losses are a problem, as are declining sugarcane yields despite high agronomic input (Bell et al., 2007; Brodie et al., 2008). In addition, manufacture of synthetic $\mathrm{N}$ fertilizer uses $\approx 2 \%$ of global energy consumption. One avenue to remediate the problem associated with synthetic $\mathrm{N}$ fertilizers is the use of microbes capable of biological $\mathrm{N}_{2}$ fixation (BNF) (de Carvalho et al., 2011). There is evidence that endophytic bacteria able to fix $\mathrm{N}_{2}$ contribute to the $\mathrm{N}$ budget of Brazilian sugarcane (Boddey et al., 2003).

The efficacy of diazotrophic bacteria varies considerably in sugarcane crops (Yoneyama et al., 1997). Further, rhizosphere bacteria including diazotrophic bacteria have cultivarspecific relationships, and sugarcane varieties may have specific controls aimed at attracting specific diazotrophs (de Carvalho et al., 2011). Therefore, it is important to isolate and characterized highly $\mathrm{N}_{2}$ fixing and growth promoting diazotrophs from sugarcane rhizosphere in Bangladesh and use of these diazotrops for making biofertilizers for commercial and environmentally safe cultivation of sugarcane. But no research works on diazotrops related to sugarcane in Bangladesh has been done yet. Keeping all this views in mind the present study was undertaken to isolate and characterization diazotrophs from sugarcane rhizosphere on the basis of $\mathrm{N}_{2}$-fixation, phytohormone production, physiological and biochemical properties.

\section{Materials and Methods}

The experiment was conducted at the Soil Microbiology Laboratory of the Department of Soil Science, Bangabandhu Sheikh Mujibur Rahman Agricultural University (BSMRAU), Gazipur during the period from January, 2011 to June, 2011 with a view to isolate and characterized promising diazotrophs from sugarcane rhizosphere.

\section{Sampling procedures for isolation of diazotroph}

Rhizosphare soil samples were collected from six locations comprising six Agro Ecological Zones (AEZ) of Bangladesh viz. Ishurdi (AEZ-11), Thakurgaon (AEZ-1), Joypurhat (AEZ-3), Gazipur (AEZ-28), Habiganj (AEZ29) and Jamalpur (AEZ-9). The samples were collected randomly from three-month aged sugarcane field. Samples of sugarcane root and root adhering soil (rhizosphere soil) were collected randomly from three sugarcane variety i.e. Isd 37, Isd 39 and Isd 40 for isolation of diazotrophs. For each region samples were collected from three locations. A composite sample were taken to the laboratory in an ice box and kept at $4^{0} \mathrm{C}$ temperature before isolation.

\section{Isolation of diazotroph from sugarcane rhizosphere}

Isolation of different diazotrophic bacteria from sugarcane rhizosphere was done in different semisolid media i.e Nfb media and Burks media. Composition of the $\mathrm{Nfb}$ medium was: $5 \mathrm{~g}$ malic acid, $0.5 \mathrm{~g} \mathrm{~K}_{2} \mathrm{HPO}_{4}$, $0.2 \mathrm{~g} \mathrm{MgSO}_{4} 7 \mathrm{H}_{2} \mathrm{O}, 0.1 \mathrm{~g} \mathrm{NaCl}$ and $0.5 \%$ bromothymol blue in $0.2 \mathrm{~N} \mathrm{KOH}(2 \mathrm{ml}), 1.64$ $\%$ Fe-EDTA solution (4 ml), $2 \mathrm{~g}_{\text {agar }} \mathrm{L}^{-1}$ for semi solid medium and $15 \mathrm{~g}$ agar $\mathrm{L}^{-1}$ for solid 
medium. The $\mathrm{pH}$ of the medium was adjusted with $\mathrm{KOH}$ to 7.20. Composition of Burks medium was: $20 \mathrm{~g}$ sucrose, $0.80 \mathrm{~g} \mathrm{~K}_{2} \mathrm{HPO}_{4}$, $0.20 \mathrm{~g} \mathrm{KH}_{2} \mathrm{PO} 4,0.13 \mathrm{~g} \mathrm{CaSO}_{4}, 0.20 \mathrm{~g} \mathrm{MgSO}_{4}$ $7 \mathrm{H}_{2} \mathrm{O}, 0.000253 \mathrm{~g} \mathrm{Na}_{2} \mathrm{MoO}_{4} .2 \mathrm{H}_{2} \mathrm{O}, 0.00145 \mathrm{~g}$ $\mathrm{FeCl}_{3} .2 \mathrm{H}_{2} \mathrm{O}, 5.0 \mathrm{ml}$ bromothymol Blue $(0.5 \%$ in ethanol), $2 \mathrm{~g}$ agar $\mathrm{L}^{-1}$ for semi solid medium and $15 \mathrm{~g}$ agar $\mathrm{L}^{-1}$ for solid medium. The $\mathrm{pH}$ of the medium was adjusted with $\mathrm{NaOH}$ to 7.00. Approximately $10 \mathrm{~g}$ of sugarcane root with adhering soil was placed in to $250 \mathrm{~mL}$ Erlenmeyer flask containing 95 $\mathrm{mL}$ sterilized water, and content was shaken for 15 to $20 \mathrm{~min}$. A series of 10 -fold dilutions were prepared up to $10^{-8}$ of rhizosphere soil. Sterilized $\mathrm{Nfb}$ and Burks semisolid medium were used for isolation of diazotrophs. Inoculation was done in test tubes containing $10 \mathrm{~mL}$ of semisolid media. From the lower dilutions $\left(10^{-3}\right.$ to $\left.10^{-7}\right) 0.1 \mathrm{~mL}$ was inoculated in each test tube. The mouth of test tube was closed with cotton plug and placed in an incubator adjusted to $28^{\circ} \mathrm{c}$ for 2 days. For purification of colonies from the pellicle formed in semisolid media bacterial cells were streaked out with a sterilized needle and inoculated again in the same semisolid media. This process was carried out five times. Then the diazotroph bacterial culture was grown in respective solid media for obtaining single colonies. From the single colonies morphological characteristics were studied and depending on different colony characters specific names of the isolates were given. These isolates were preserved in slant of specific medium with addition of glycerol and oil emulsion. All isolates were also preserved in eppendorf tube containing $1 \mathrm{~mL} 20 \%$ glycerol solution and incubated at $-20^{\circ} \mathrm{C}$ prior to characterization. Each isolate was preserved in several numbers of slants and eppendorf tube for further use.

\section{Characterization of diazotrophic isolates:}

A preliminary experiment was conducted in the Soil Microbiology laboratory of the
Bangabandhu Sheikh Mujibur Rahman Agricultural University to characterize all of the isolates. Biochemical characteristics of different diazotrophic isolates were determined on the following aspects: Gram reaction, $\mathrm{KOH}$ test, acetylene reduction assay, IAA production, and cellulose degrading activity and phosphate solubilizing assay.

\section{Gram staining and $\mathrm{KOH}$ test}

About $48 \mathrm{~h}$ of pure bacterial isolates were tested for Gram staining and $\mathrm{KOH}$ test. Gram staining slides were prepared by heat fixed smear of bacteria flooded with two drops of crystal violet for one minute. The crystal violet was then gently washed off with sterilized distilled water. The smear was sealed with iodine for one minute followed by washing with water. Using a Pasteur pipette alcohol solution was gently dropped to remove the stain. After washed with water the smear was counter stained with safranine for $30 \mathrm{sec}$. The slides were washed with sterilized distilled water and air dried. The stained smear was observed under the light microscope using oil emulsion at $10 x$ to $100 x$ magnification.

A Gram-positive strain appeared bluish or purple and Gram-negative strain was reddish in colour (Naher et al., 2009). For KOH test, pure culture isolates from media plates were dropped on slides and one drop of freshly prepared $3.0 \% \mathrm{KOH}$ was added and mixed with culture with the help of sterile needle. The Gram-negative bacteria suspension becomes thick and sticky while Gram positive remain the same (Naher et al., 2009).

\section{Determination of cellulase activity}

The cellulase activity was determined according to James et al., (2002). The bacterial culture was grown in Jensen's broth and incubated for 48 hours. Cellulose degradation was carried out on Jensen's agar 
plates with $0.1 \%$ carboxymethyl cellulose (CMC). Plates were spot inoculated with 10 $\mu 1$ liquid culture of the strains. After 24 hours of incubation period the colonies were streaked and washed off with sterile water and discarded. The plates were stained with $0.1 \%$ Congo red solution for $30 \mathrm{~min}$. After stained, plates were rinsed with $1 \mathrm{M} \mathrm{NaCl}$. The cellulose degrading enzyme activated plates showed clear hallo zone. The hallo-zones indicated positive in reaction.

\section{Phosphate solubilizing assay}

Test for P-solubilisation was done following Sharma et al., (2012). The plates were prepared with Pikovaskya's medium. The cultures of diazotroph isolates were spot inoculated on the plates and incubated in an incubator at $28^{\circ} \mathrm{C}$ for 3- 5 days. Formation of clear zone around the microbial colonies indicated phosphate solubilization. Composition of Pikovskaya media in 1 litre: Glucose-10 g, $\mathrm{Ca}_{3}\left(\mathrm{PO}_{4}\right)_{2}-5 \mathrm{~g},\left(\mathrm{NH}_{4}\right)_{2} \mathrm{SO}_{4}-0.5$ g, NaCl-0.2 g, MgSO $4.7 \mathrm{H}_{2} \mathrm{O}-0.1 \mathrm{~g}, \mathrm{KCL}-0.2$ $\mathrm{g}$, Yeast extract-0.5 g, $\mathrm{MnSO}_{4} \cdot \mathrm{H}_{2} \mathrm{O}-0.002 \mathrm{~g}$, $\mathrm{FeSO}_{4} .7 \mathrm{H}_{2} \mathrm{O}-0.002 \mathrm{~g}$ and Agar-15 g (Pikovskaya, 1948).

\section{Estimation of nitrogenase enzyme activity (acetylene reduction assay)}

A $1.0 \mathrm{~mL}$ of the culture was transferred into an air-tight $30 \mathrm{ml}$ bottle containing $10 \mathrm{ml}$ of $\mathrm{Nfb}$ semi-solid medium. After the pellicle formation $(72 \mathrm{~h})$, the bottles were injected with $5 \% \quad(\mathrm{v} / \mathrm{v})$ acetylene gas with simultaneous removal of the same volume of air. The bottles then incubated at $30^{\circ} \mathrm{C}$ for 24h. $1 \mathrm{ml}$ of gas was withdrawn and transferred to $7 \mathrm{ml}$ Vacutainer ${ }^{\mathrm{TW}}$ tubes. The ethylene gas produced was measured using G300 gas chromatograph (American TM) equipped with an FID and 1-m Porapak N column (Naher et al., 2009).

\section{IAA production}

Both Rhizobium and diazotrophic isolates were inoculated in Jensen's broth with addition of tryptophan $\left(2 \mathrm{mg} \mathrm{mL} \mathrm{mL}^{-1}\right)$ and incubated at $28 \pm 2^{0} \mathrm{C}$ for $48 \mathrm{~h}$. The culture was then centrifuged at $7000 \mathrm{rpm}$ for $7 \mathrm{~min}$ and $1 \mathrm{~mL}$ of the supernatant was mixed with 2 $\mathrm{ml}$ of Salkowsky's reagent. The IAA concentration was determined using spectrophotometer at $535 \mathrm{~nm}$ (Naher et al., 2009).

\section{DNA extraction}

\section{Isolation of genomic DNA}

For genomic DNA isolation, selected bacterial isolates were cultured in nutrient broth at $27^{\circ} \mathrm{C}$ and $120 \mathrm{rpm}$ in a shaker incubator. About 24 hours old cultures were subjected for genomic DNA isolation. A commercial DNA extraction kit (manufactured by ATP Genomic DNA Mini Kit, ATP Biotech Inc.) was used and the genomic DNA was extracted following the instructions of the manufacturer. The polymerase chain reaction (PCR) for amplification of the targated 16SrDNA of the two-representative presumptive isolates BUSo 9 and BUSo13 was performed with the universal primer sets $24 \mathrm{~F}$ (forward primer) and $1540 \mathrm{R}$ (reverse primer). For amplification of soil bacterial isolates, Streptomyces genus specific primer set Streptom F and Streptom R was used. All primers (Sigma Ltd.) were preserved in the Biotechnology Laboratory, BSMRAU, Gazipur which have been routinely used for molecular identification of fish pathogenic and soil bacteria. Sequences of these primers are given in Table 1.

The PCR amplification was performed in a PCR Thermocycler (Eppendrof Ltd). The PCR product was purified by using a 
commercial Gel/PCR Purification Kit (FavorPrepTM, Favorgen ${ }^{\circledR}$ Biotech Corp) following the manufacturer's protocol.

\section{DNA sequencing}

The purified PCR products of the soil bacteria and potential antimicrobial agent producing soil bacterial isolates along with sequencing primer were sent to the laboratory of Centre for Advanced Research in Sciences (CARS), Dhaka University for 16sRDNA sequencing.

\section{Phylogenetic analysis}

DNA sequences (FASTA format) of the isolates were then used for DNA sequence homology study and phylogenetic analysis using the BLAST and Phylogeny.fr web based soft ware.

\section{Results and Discussion}

\section{Gram staining and $\mathrm{KOH}$ test}

The diazotroph isolated from different sugarcane growing regions were tested for Gram reaction and $\mathrm{KOH}$ test. Among the 24 isolated strains 13 of them were found as Gram negative and 11 were Gram positive. The $\mathrm{KOH}$ test showed that 13 of the strains were positive and 11 were negative in $\mathrm{KOH}$ reaction (Table 2).

\section{Cellulase activity}

Jensen-CMC plate assayed to determine cellulose activity. The plates spoted with diazotrophic broth showed a clear halo zone after stained with $0.1 \%$ Congo red indicating cellulose activity. Seventeen of the rhizosphere isolates were positive for cellulose activity (Plate 1).

\section{Phosphate solubilizing activity}

Pikovskaya plates were assayed to determine
Phosphate solubilizing activity (Plate 2). The cultures of diazotroph isolates were spot inoculated on the plates and incubated in an incubator at $28^{\circ} \mathrm{C}$ for 3- 5 days.

Fifteen of the diazotroph isolates were found as positive for phosphate solubilization activity.

\section{Acetylene reduction assay (ARA)}

Twenty-four bacterial strains were evaluated for nitrogen fixation activity (Table 2). The ARA value ranges from $5.16 \times 10^{-10}$ to $3.74 \mathrm{x}$ $10^{-4} \mu \mathrm{mol} \mathrm{C}_{2} \mathrm{H}_{4} \mathrm{cfu}^{-1} \mathrm{hr}^{-1}$. The highest ARA was found in isolate BUSo $9\left(3.74 \times 10^{-4}\right.$ $\mu \mathrm{mol} \mathrm{C}_{2} \mathrm{H}_{4} \mathrm{cfu}^{-1} \mathrm{hr}^{-1}$ ) which was statistically at par with BUSo $13\left(1.54 \times 10^{-4} \mu \mathrm{mol} \mathrm{C}_{2} \mathrm{H}_{4} \mathrm{cfu}^{-}\right.$ ${ }^{1} \mathrm{hr}^{-1}$ ) and the lowest was obtained from BuSo $24\left(5.16 \times 10^{-10} \mu \mathrm{mol} \mathrm{C} \mathrm{C}_{2} \mathrm{H}_{4} \mathrm{cfu}^{-1} \mathrm{hr}^{-1}\right)$. Several isolates were high in ARA as observed for BUSo 3, BUSo 19, BUSo 20 and BUSo 6 . Many researchers reported that diazotrophic bacteria have been linked with the high nitrogen fixation reported particularly in sugarcane where these bacteria were found in high numbers (Boddey et al., 1991, 1995 a, b; Döbereiner et al., 1995 a, b; James and Olivares, 1997).

\section{Indoleacetic acid (IAA) production}

Isolated diazotroph were able to produce high amount of IAA (Fig.1). Appearance of red colour indicating IAA production by Diazotrophs (Plate 1). IAA production of isolates differed significantly among strains. In the presence of tryptophan the bacterial isolates produced higher IAA which varied from 30 to $180 \mu \mathrm{g} \mathrm{mL}^{-1}$. The highest IAA was recorded in strain BUSo $5\left(180 \mu \mathrm{g} \mathrm{mL}^{-1}\right)$ followed by strain BUSo 3 and BUSo 22 (both $150 \mu \mathrm{g} \mathrm{mL}^{-1}$ ). This finding was at par with that of Keyeo et al., (2011) reported rice diazotrophs produces phytohormone indole-3acetic acid (IAA) in different concentration. 


\section{Identification of diazotrophs}

Quantification of bacterial genomic DNA of Acinetobacter calcoaceticus (BUSo 9) and Bacillus cereus (BUSo 13) compare with $1 \mathrm{~kb}$
DNA ladder (AccuLadder, BIONEER) as a Marker (L1) was shown in Figure 2. PCR amplification of Acinetobacter sp. Isolate (BUSo 9) and Basillus sp. Isolate (BUSo 13) was shown in Figure 3.

Table.1 Primer sequences used for PCR amplification (Primer pair Sequence (5'-3') and Expected PCR amplicon size (bp)

\begin{tabular}{|c|c|c|}
\hline Primer pair & Sequence (5'-3') & $\begin{array}{c}\text { Expected PCR amplicon } \\
\text { size (bp) }\end{array}$ \\
\hline $\mathbf{2 4 ~ F}$ & AGAGTTTGATCCTGGCT & \\
\hline $\mathbf{1 5 4 0 R}$ & AAGGAGGTGATCCTGGCT & 1516 \\
\hline
\end{tabular}

Table.2 Biochemical characteristics of isolates obtained from rhizosphere soils

\begin{tabular}{|c|c|c|c|c|c|}
\hline Isolates & $\begin{array}{c}\text { Gram } \\
\text { reaction }\end{array}$ & $\begin{array}{c}\mathrm{KOH} \\
\text { reaction }\end{array}$ & $\begin{array}{c}\text { Cellulose } \\
\text { degradation }\end{array}$ & P solubilization & $\frac{\text { ARA }}{\left(\mu \mathrm{mol} \mathrm{C}_{2} \mathbf{H}_{4}{ }^{-1} \mathrm{cfu}^{-1} \mathbf{h}^{-1}\right)}$ \\
\hline BUSo1 & + & - & - & - & $\mathrm{Nd}^{*}$ \\
\hline BUSo2 & + & - & - & - & $\mathrm{Nd}^{*}$ \\
\hline BUSo 3 & - & + & + & + & $8.56 \times 10^{-5} \mathrm{~b}$ \\
\hline BUSo 4 & + & - & - & + & $7.44 \times 10^{-7} \mathrm{f}$ \\
\hline BUSo 5 & - & + & + & - & $7.99 \times 10^{-10} \mathrm{f}$ \\
\hline BUSo 6 & - & + & - & + & $1.36 \times 10^{-7} \mathrm{~cd}$ \\
\hline BUSo 7 & + & - & + & + & $5.48 \times 10^{-9} \mathrm{f}$ \\
\hline BUSo 8 & - & + & + & + & $8.61 \times 10^{-10} \mathrm{hi}$ \\
\hline BUSo 9 & - & + & + & + & $3.74 \times 10^{-4} \mathrm{a}$ \\
\hline BUSo10 & + & - & + & - & $3.26 \times 10^{-9} \mathrm{fg}$ \\
\hline BUSo11 & - & + & + & + & $9.38 \times 10^{-10} \mathrm{hi}$ \\
\hline BUSo12 & - & + & + & - & $14.89 \times 10^{-10} \mathrm{gh}$ \\
\hline BUSo13 & + & - & + & + & $1.54 \times 10^{-4} \mathrm{ab}$ \\
\hline BUSo14 & + & - & + & + & $8.97 \times 10^{-9} \mathrm{f}$ \\
\hline BUSo15 & + & - & - & + & $5.44 \times 10^{-9} \mathrm{f}$ \\
\hline BUSo 16 & - & + & - & - & $\mathrm{Nd}^{*}$ \\
\hline BUSo 17 & - & + & + & + & $5.65 \times 10^{-8} \mathrm{de}$ \\
\hline BUSo 18 & + & - & + & - & $8.46 \times 10^{-8} \mathrm{cde}$ \\
\hline BUSo 19 & - & + & + & + & $2.11 \times 10^{-7} \mathrm{c}$ \\
\hline BUSo 20 & + & - & - & + & $2.26 \times 10^{-7} \mathrm{c}$ \\
\hline BUSo 21 & + & - & + & + & $3.94 \times 10^{-8} \mathrm{e}$ \\
\hline BUSo 22 & - & + & + & - & $13.10 \times 10^{-10} \mathrm{ghi}$ \\
\hline BUSo 23 & - & + & + & + & $5.90 \times 10^{-8} \mathrm{hi}$ \\
\hline BUSo 24 & - & + & + & - & $5.16 \times 10^{-10} \mathrm{i}$ \\
\hline LSD (0.05) & - & - & - & - & 0.22 \\
\hline
\end{tabular}

Means followed by uncommon letters are statistically different from each other at $5 \%$ level of provability by DMRT $* \mathrm{Nd}=$ Not detected 
Plate.1 Cellulase activity assayed after 24 hours incubation in Jensen-CMC plate the clear halo zone indicates cellulose degradation

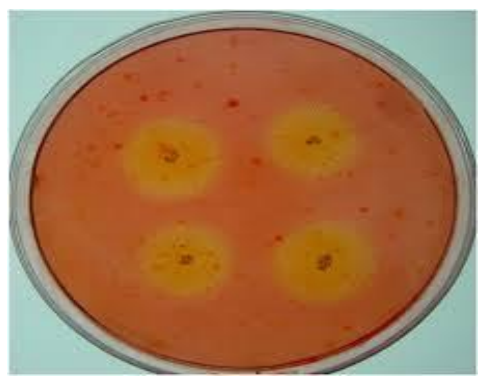

Plate.2 Phosphate solubilizing activity assayed after 5 days incubation in Pikovskaya plate. The formation of clear zone around the microbial colonies indicated phosphate solubilization.

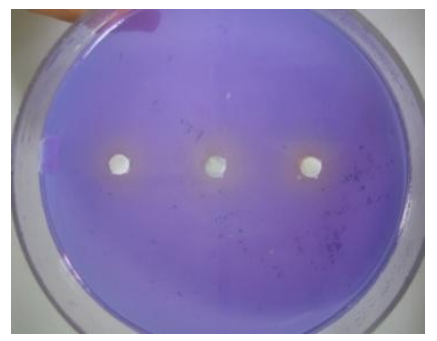

Plate.1 Appearance of red colour indicating IAA production by Diazotrophs

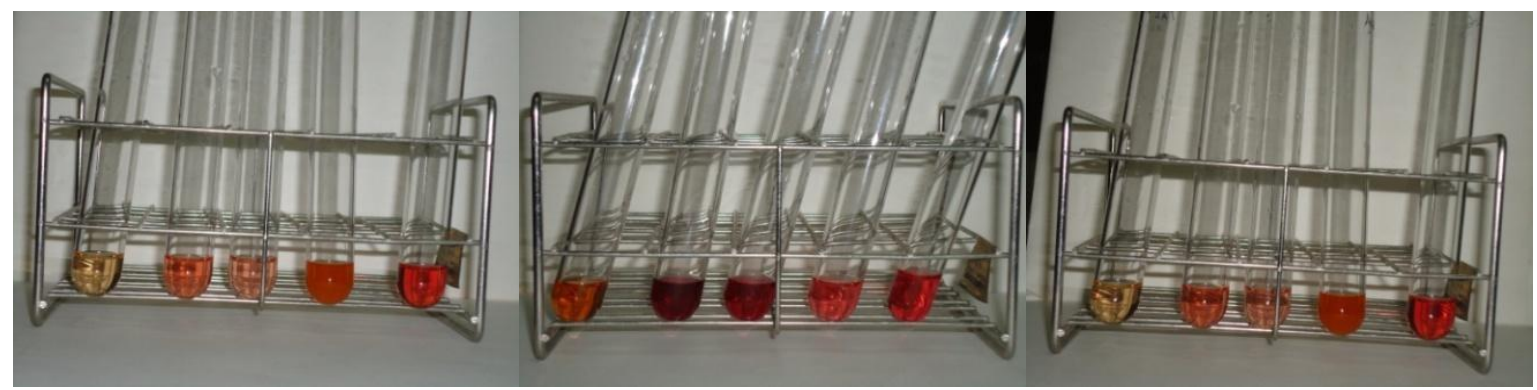

Figure.1 IAA production of the isolated diazotroph from sugarcane soil-plant system Vertical bars represent standard error of treatment means

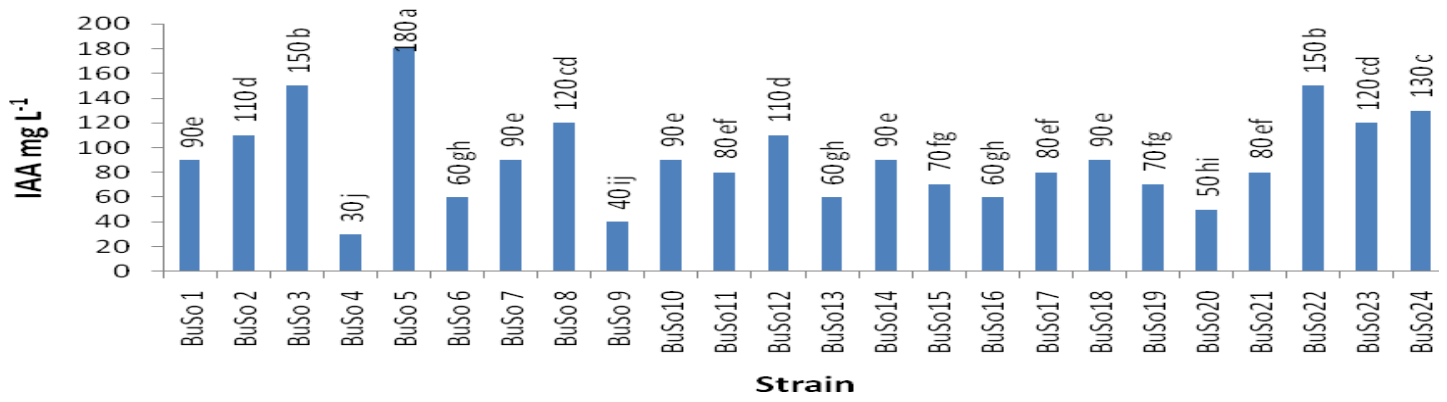

Means followed by uncommon letters are statistically different from each other at 5\% level of provability by DMRT 
Figure.2 Quantification of bacterial genomic DNA of Acinetobacter calcoaceticus (BUSo 9) and Bacillus cereus (BUSo 13) compare with $1 \mathrm{~kb}$ DNA ladder (AccuLadder, BIONEER) as a Marker (L1)

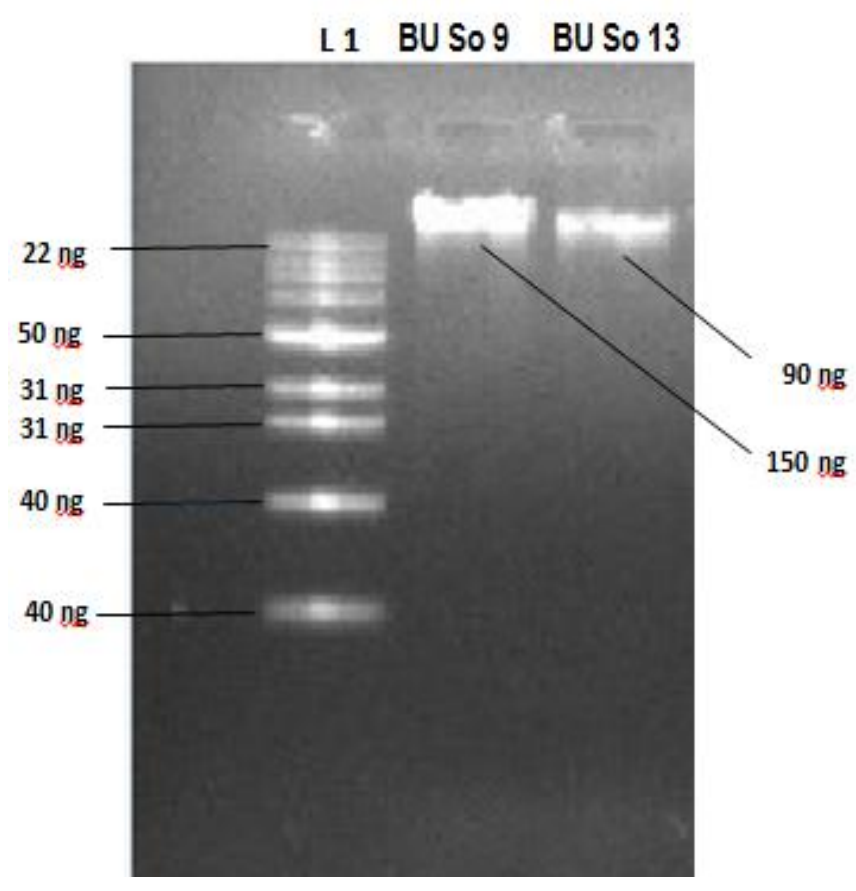

Figure.3 PCR amplification of Acinetobacter sp. Isolate (BUSo 9) and Basillus sp. Isolate (BUSo 13)

\section{L1 BUSO 9 BUSO 13}

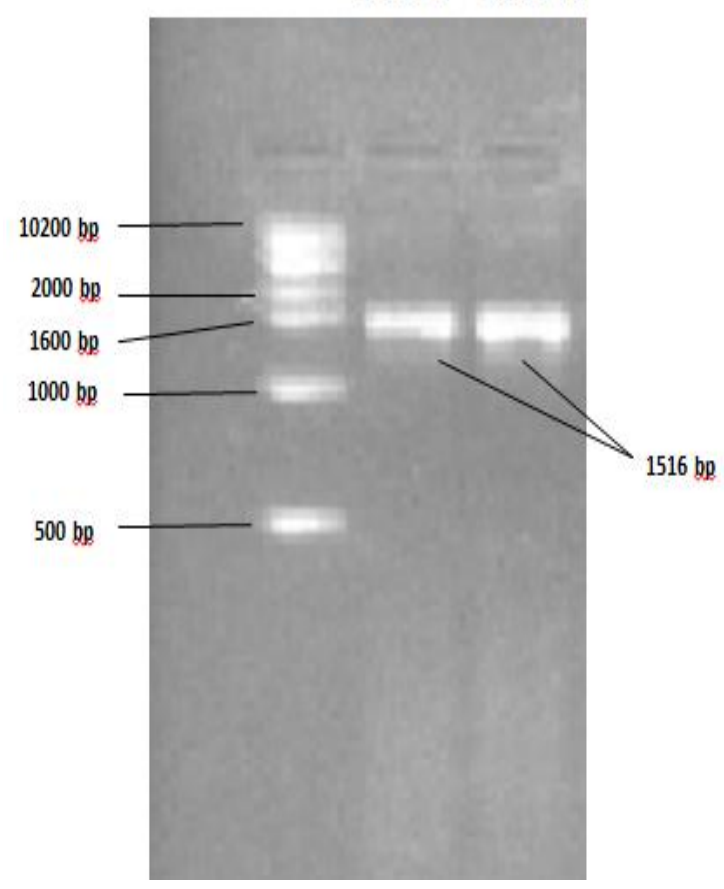


Figure.4 Phylogenetic tree of diazotrophic isolates BUSo 9

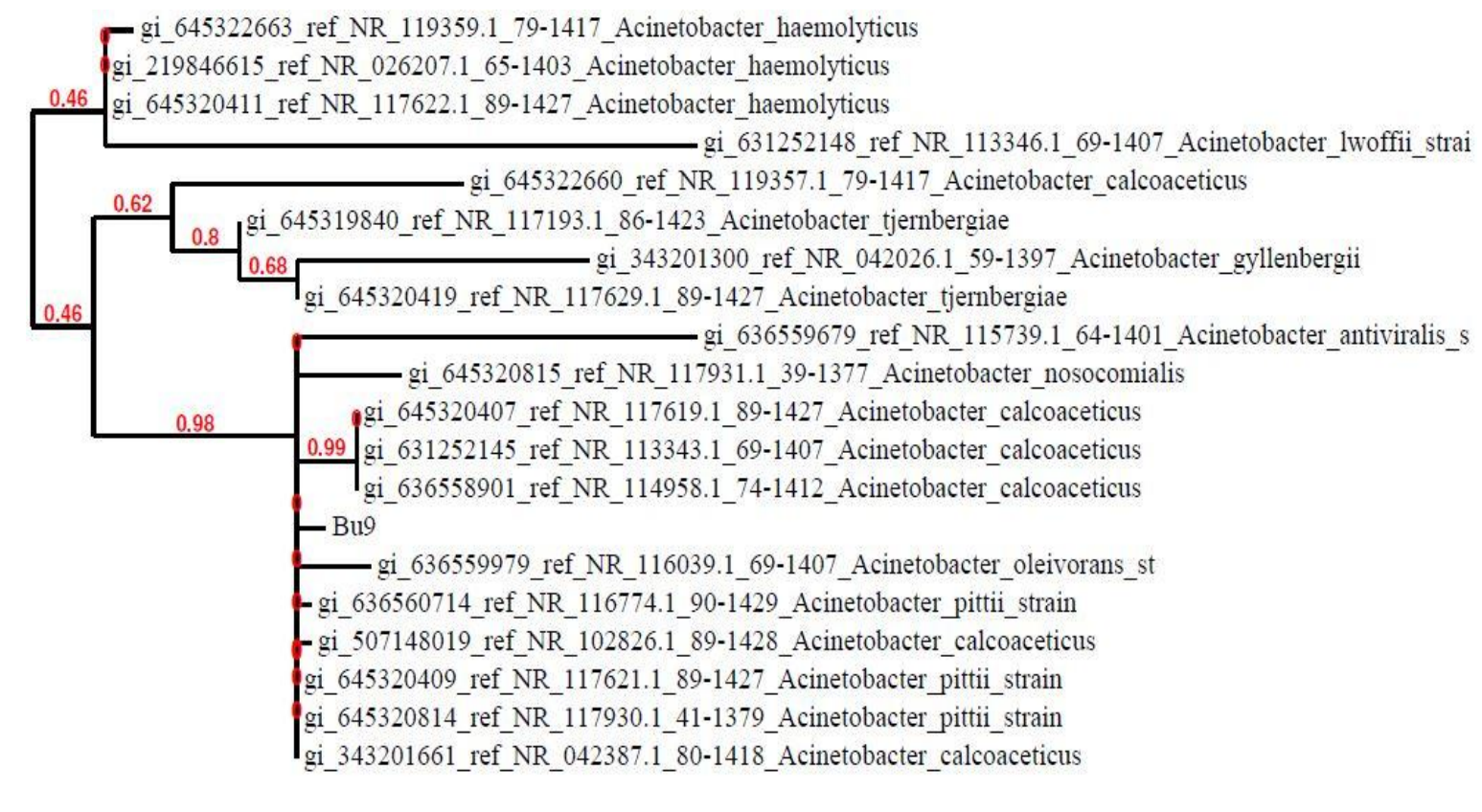

0.02

Figure.5 Phylogenetic tree of diazotrophic isolates BUSo 13

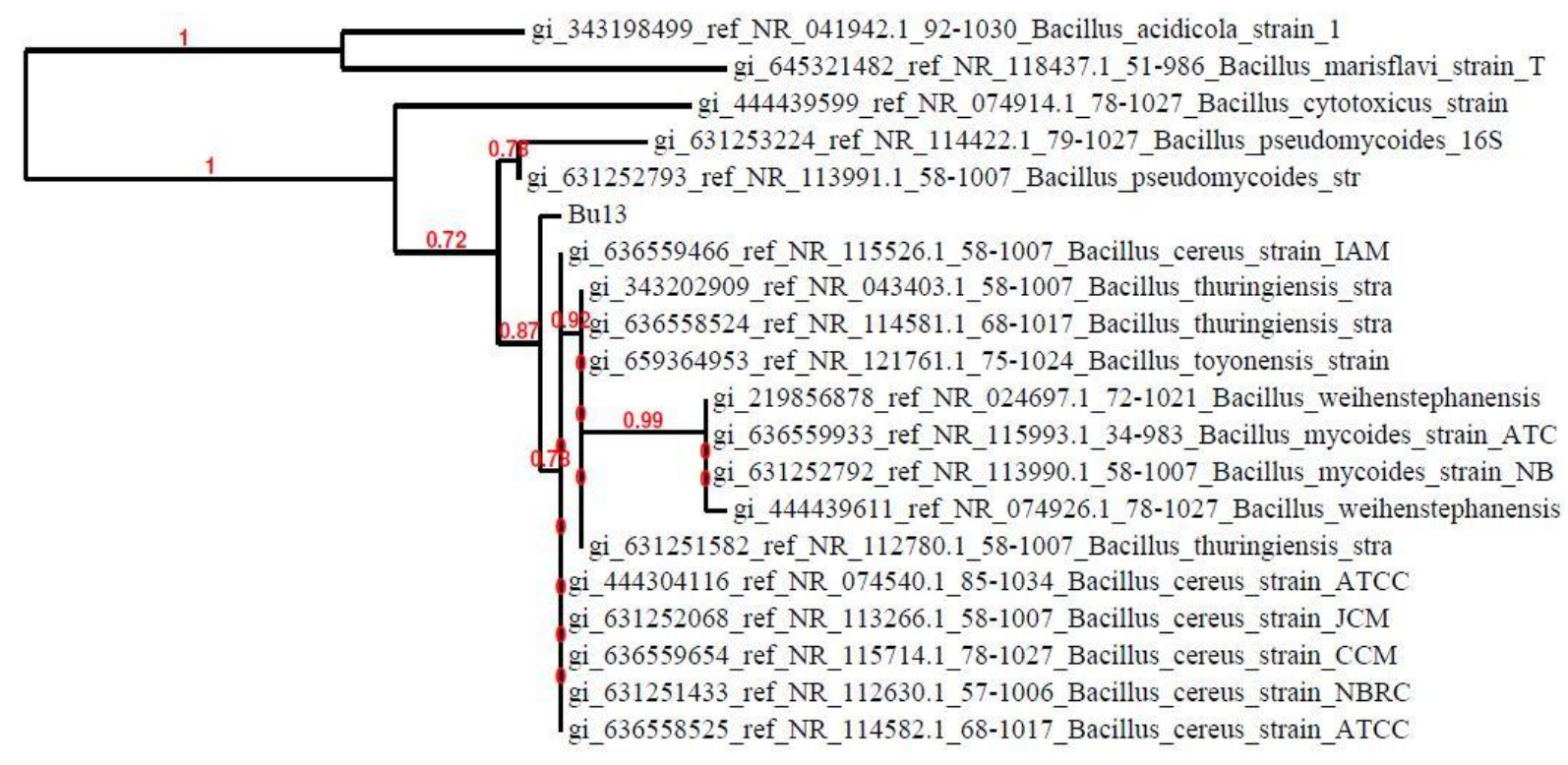

0.01

From 16S rDNA sequence analysis of the strains it was observed that 99 percent sequence identity was observed between the $16 \mathrm{~S}$ rDNA sequence of BUSo 9 and
Acinetobacter calcoaciticus (Fig 4) and the 16S rDNA sequence of BUSo 13 and Bacillus cereus (Fig. 5). 
Isolation of all the above bacteria was already reported from different crops by many researchers (Orhan et al., 2006, Rodriguez \& Fraga, 1999; Sturz and Nowak, 2000; Sahin et al., 2004, Kang et al, 2012). Some researcher reported that free-living $\mathrm{N}_{2}$-fixing bacteria belonging to the genera Beijerinckia, Azospirillum, Azotobacter, Bacillus, Derxia, Enterobacter, and Erwiniaappear to be frequent colonizers of sugarcane (Döbereiner and Ruschel 1958; Arias et al., 1978; Hegazi et al., 1979; Purchase, 1980; Rennie et al., 1982; Graciolli et al., 1983; Seldin et al., 1984).

Based on this result, strains BUSo 9 and BUSo 13 were identified as Acinetobacter calcoaciticus and Bacillus cereus, respectively. Under in vitro conditions, both of the strains exhibited a high nitrogenase activity and produced a substantial amount of IAA. Chakraborty et al., (2006) reported Bacillus sp. from tea rhizosphere is able to produce IAA and thus helps in the plant growth promotion. Husen, (2003) observed that bacterial strains Bacillus cereus when tested in vitro are found to solubilize phosphate and thus help in growth of plant. Çakmakçi et al., (2006) observed that three different Bacillus isolates fixed nitrogen and increased growth in sugarbeet in a greenhouse study. Dadook et al., (2013) repoted Acinetobacter calcoaceticusas a nitrogen fixing diazotrophs which was isolated from asparagus rhizosphere. Previously research studies on Acinetobacter focused on growth potential, indole-3-acetic acid (IAA) production, inorganic phosphate solubilization, and nitrogen fixation (Huddedar et al., 2002; Indiragandhi et al., 2008; Khan et al., 2011b).

From the above results it may be concluded that among tweenty four bacterial strains 21 isolates were found as ARA positive. The highest ARA was found in strain
Acinetobacter calcoaciticus (BUSo 9) (3.74 x $\left.10^{-4} \mu \mathrm{mol} \quad \mathrm{C}_{2} \mathrm{H}_{4} \quad \mathrm{cfu}^{-1} \mathrm{hr}^{-1}\right)$ which was statistically similar to Bacillus cereus (BUSo 13) $\left(1.54 \times 10^{-4} \mu \mathrm{mol} \mathrm{C}_{2} \mathrm{H}_{4} \mathrm{cfu}^{-1} \mathrm{hr}^{-1}\right)$. All of the strains were found as IAA producing. Among twenty-four, thirteen strains were found as Gram negative and eleven were Gram positive. Seventeen of the strains were positive for cellulose activity. Fifteen of the strains were found as positive for phosphate solubilization activity. For identification of bacteria from the isolated strains two promising strains were selected for 16SrDNA sequencing. From $16 \mathrm{~S}$ rDNA sequence analysis of the strains it was observed that ninety nine percent sequence identity was observed between the 16S rDNA sequence of BUSo 9 and Acinetobacter calcoaciticus and also ninty nine percent sequence identity was observed between the 16S rDNA sequence of BUSo 13 and Bacillus cereus.

\section{References}

Arias, O.E., Gatti, I.M., Silva,D.M., Ruschel, A.P. and Vose, P.B.1978. Primeirasobservaciones al microscopioeletronico de bacteriasfijadoras de $\mathrm{N} 2$ en la raiz de la cana de azucar (Saccharum officinarum. L.). Tarrialba, 28: 203-207.

Baldani, V.L.D., Oliveira, E., Balota, E., Baldani, J.I., Kirhhof, G., Döbereiner, J. 1997. Burkholderia brasilensesp. nov., a new species of diazotrophic endophytic bacteria. Anais da Academia Brasileira de Ciências 69: 116-166 (in Portuguese, with abstract in English).

Bell, M.J., Stirling, G.R., and Pankhurst, C.E. 2007. Management impacts on health of soils supporting Australian grain and sugarcane industries. Soil Till Res 97: 256-271.

Boddey, R. M., Urquiaga, S., Reis, V. M. and Döbereiner, J. 1991. Biological nitrogen fixation associated with sugarcane. 
Plant Soil 137: 111-117.

Boddey, R.M., Oliveira, O.C.de., Urquiaga, S. Reis, V.M., Olivares, F.L., Baldani, V.L.D. and Dobereiner, J. 1995a. Biological nitrogen fixation associated with sugarcane and rice. Contribution and prospects for improvement. Plant Soil, 174:195-209.

Boddey, R. M., Reis, V. M., Urquiaga, S., DaSilva, L. G., dosReis, F. B., Baldani, J.I and Döbereiner, J. 1995b. $\mathrm{N}_{2}$ fixation in sugar cane: the role of Acetobacter diazotrophicus. In Nitrogen Fixation: Fundamental and Applications. Eds. I A Tikhonovich, N A Rovorov and W. E. Newton. pp 641-646, Kluwer Academic Publishers, Dordrecht, TheNetherlands.

Boddey, R.M., Urquiaga, S., Alves, J.R.A., Reis, V.M.2003. Endophytic nitrogen fixation in sugarcane: present knowledge and future applications. Plant and Soil, 252: 139-149

Brodie, J., Binney, J., Fabricius, K., Gordon, I., Hoegh-Guldberg, O., Hunter, H., et al., 2008. Synthesis of Evidence to Support the Scientific Consensus Statement on Water Quality in the Great Barrier Reef . Brisbane, Qld, Australia: The State of Queensland (Department of the Premier and Cabinet), Reef Water Quality Protection Plan Secretariat.

Çakmakçi, R., Donmez, F., Aydın, A. and Sahin, F. 2006. Growthpromotion of plants by plant growth promoting rhizobacteria under greenhouse and two different field soil conditions. Soil Biol. Biochem., 38: 1482-1487.

Chakraborty, U., Chakraborty, B., Basnet, M. 2006.Plant growth promotion and induction of resistance in Camellia sinensis by Bacillus megaterium.J Basic Microbiol, 46 (Suppl 3): 186 - 195.

Dadook, M. Mehrabian, S. and Irian, S. 2013.Identification of ten N2-fixing bacteria using $16 \mathrm{~S}$ rRNA and their response to various zinc concentrations.
Int. J. Cell. Mol. Biotechnol.:1-8, Available online at www.ispacs.com/ijcmb

de Carvalho, T.L.G., Ferreira, P.C.G., and Hemerly, A.S.2011. Sugarcane genetic controls involved in the association with beneficial endophytic nitrogen fixing bacteria. Trop. Plant Biol., 4: 31-41.

Döbereiner, J, Baldani, V.L.D. and Reis, V.M. 1995a. Endophytic occurrence of diazotrophic bacteria in non-leguminous crops. In Azospirillum VI and Related Micro-organisms. Eds. I Fendrik, $M$ del Gallo, $\mathbf{J}$ Vanderleyden and $\mathrm{M}$ de Zamaroczy. pp 3-14. Springer- Verlag, Berlin.

Döbereiner, J. Urquiaga, S. and Boddey, R.M. 1995b. Alternatives for nitrogen nutrition of crops in tropical agriculture. Fertil. Res. 42: 339-346.

Döbereiner, J. and Pedrosa, F.O. 1987. Nitrogen Fixing Bacteria in NonLeguminous Crop Plants. Brock/Springer, Madison, WI, USA (Science Technology Brock/Springer Contemporary Bioscience Series).

Döbereiner, J., Ruschel, A.P. 1958.A new species of Beijerinckia. Revista de Biologia, 1: 261-272 (in Portuguese, with abstract in English).

Gillis, M., Tran Van, V., Bardin, R., Goor, M., Hebbar, P., Willems, A., Segers, P., Kersters, K., Heulin, T. and Fernandez, M.P. 1995. Polyphasic taxonomy in the genus Burkholderia leading to an emended description ofthe genus and proposition of Burkholderia vietnamiensis sp. nov. for N2fixingisolates from rice in Vietnam. Int. J. Syst. Bacteriol. 45:274-289.

Graciolli, L.A., Freitas, J.R. and Ruschel, A. P.1983. Bacterias fix adoras de nitrogenionasraizes, caules e folhas de cana-de-acucar (Saccharum sp.). Rev. Microbiol. 14: 191-196. 
Hegazi, N.A., Eid, M., Farag, R.S. and Monib, M.1979.Asymbiotic $\mathrm{N}_{2}$-fixation in the rhizosphere of sugarcane planted under semiarid conditions of Egypt. Rev. Biol. Soil, 16:23-37

Huddedar, S.B., Shete, A.M., Tilekar, J.N., Gore, S.D., Dhavale, D.D. and Chopade, B.A. 2002. Isolation, characterization and plasmid pUPI126 mediated indole-3-acetic acid (IAA) productions in Acinetobacter strains from rhizosphere of wheat. App. Biochem. Biotech., 102- 103: 21-29.

Husen, E. 2003. Screening of soil bacteria for plant growth promoting activities in vitro. Indones. J. Agric. Sci., 4: 27-31.

Indiragandhi, P., Anandham, R. Madhaiyan, M. and Sa, T.M. 2008. Characterization of plant growth-promoting traits of bacteria isolated from larval guts of Diamondback moth Plutella xylostella (Lepidoptera: Plutellidae). Curr.Microbiol., 56: 327-333.

James, E. K., Gyaneshwar, P., Mathan, N., Barraquio, W. L., Reddy, P. M., Iannetta, P. P. M., Olivars, F. L., and Ladha, J. K. 2002. Infection and colonization of rice seedlings by the plant growth-promoting bacterium Herbaspirillum seropedicae Z.67.Mol. Plant Microbe Interact., 15: 894-906.

James, E.K. and Olivares, F.L. 1997. Infection and colonization of sugarcane and other graminaceous plants by endophytic bacteria. Cri. Rev. Plant Sci., 17: 77-119.

Kang, S., Khan, A.L., Hamayun, M., Shinwari, Z.K., Kim, Y., Joo, G. and Lee, I. 2012. Acinetobacter calcoaceticus ameliorated plant growth and influenced gibberellins and functional biochemical. Pak. J. Bot., 44(1): 365-372.

Keyeo, F., Shah, O. N. A. and Amir, H. G. 2011. The effect of nitrogen fixation activity and phytohormone production of diazotroph in promoting growth of rice seedlings. Biotechnol., 10(3): 267273.

Khammas, K.M., Ageron, E., Grimont, P.A.D., Kaiser, P. 1989. Azospirillum irakensesp. nov., a nitrogen fixing bacterium associated with rice roots and rhizosphere soil. Res. Microbiol., 140: 679-693.

Khan, A.L., Hamayun, M., Waqas, M., Kang, S.M., Kim,Y.H. Kim, D.K. and Lee, I.J. 2011b. Exophiala sp. LHL08 association gives heat stress tolerance by avoiding oxidative damage to cucumber plants. Biol. Fertil. Soils. DOI 10.1007/s00374-011-0649-y.

Magalhaes, F.M.M., Patriquin, D., Döbereiner, J. 1979. Infection of field grown maize with Azospirillum. Revista Brasileira de Biologia, 39: 587-596.

Naher, U.A., Othman, R., Shamsuddin, Z. H. J., Saud, H. M. and Ismail, H. R. 2009.Studies on Diazotrophs from Rice Fields. Int. J. Agric. Biol., Vol. 11 (5): 547-551.

Neal, J.L., Larson, R.I. 1976. Acetylene reduction by bacteria isolated from rhizosphere of wheat. Soil Biol. Biochem., 8: 151-155.

Orhan, E., Esitken, A., Ercisli, S., Turan, M., Sahin, F. 2006. Effects of plant growth promoting rhizobacteria (PGPR) on yield, growth and nutrient contents in organically growing raspberry. Sci. Hortic- Amsterdam, 111 (suppl 1): 3843.

Pikovskaya, R.I. 1948. Microbiol., 17: 362370.

Purchase, B.S.1980. Nitrogen fixation associated with sugarcane. In: Proceedings of the South Afr. Sugar Technol.Assoc., pp 173-176.

Reis, V.M., Olivares, F.L., Döbereiner, J. 1994. Improved methodology for isolation of Acetobacter diazotrophicus and confirmation of its endophytic 
habitat. World J. Microbiol.Biotechnol., 10: 401-405.

Reis, V.M., Estrada-de Los Santos, P., Tenorio-Salgado, S., Volgel, J., Stoffels, M., Guyon, S., Mavingui, P., Baldani, V.L.D., Schmid, M., Baldani, J.I., Balandreau, J., Hartmann, A., Caballero-Mellado, J. 2004. Burkholderia tropica sp. nov., a novel nitrogen-fixing, plant-associated bacterium. Int. J. Syst. Evol. Microbiol., 54: 2155-2162.

Rennie, R.J., Freitas, J.R.D., Ruschel, A.P., Vose, P.B.1982. Isolation and identification of $\mathrm{N}_{2}$-fixing bacteria associated with sugarcane (Saccharum sp.). Can. J. Microbiol. 28: 462-467.

Rodriguez, H. and Fraga,R. 1999. Phosphate solubilizing bacteria and their role in plant growth promotion. Biotechnol. Adv., 17: 319-339.

Sahin, F., R. Cakmakci and F. Kantar. 2004. Sugar beet andbarley yields in relation to inoculation with $\mathrm{N}_{2}$-fixing and phosphate solubilizing bacteria. Plant Soil., 265: $123-129$.

Seldin, L., Van Elsas, J.D. and Penido,
E.G.C.1984. Bacillus azotofixans sp. Nov., a nitrogen fixing species from Brazilian soils and grass roots. Int. J. Syst. Bacteriol. 34: 451-456.

Sharma, B.C., Subba, R., Saha, A. 2012. Invitro solubilization of tricalcium phosphate and production of IAA by phosphate solubilizing bacteria isolated from tea rhizosphere of Darjeeling Himalaya. Plant Sci. Feed., 2 (6): 96-99.

Sturz, A.V. and J. Nowak. 2000. Endophytic communities of rhizobacteria and the strategies required to create yield enhancing associations with crops. Applied Soil Ecol., 15: 183-190.

Xie, C.H., Yokota, A. 2005. Azospirillum oryzaesp. nov., a nitrogen fixing bacterium isolated from roots of the rice plant Oryzasativa. Int. J. Syst. Bacteriol., 55: 1435- 1438.

Yoneyama, T., Muraoka, T., Kim, T.H., Dacanay, E.V. and Nakanishi, Y. 1997.The natural N-15 abundance of sugarcane and neighbouring plants in Brazil, the Philippines and Miyako (Japan). Plant Soil, 189:239-244.

\section{How to cite this article:}

Hossain, G. M. A., A. R. M. Solaiman, A. J. M. S. Karim, G. K. M. M. Rahman, M. A. Baset, M. M. Rahman and Dev, S. 2020. Characterization of Diazotrophs Isolated from Sugarcane Rhizosphere in Different Regions of Bangladesh. Int.J.Curr.Microbiol.App.Sci. 9(03): 26432655. doi: https://doi.org/10.20546/ijcmas.2020.903.302 